\title{
Job Seekers’ Acceptance of Job Recommender Systems: Results of an Empirical Study
}

\author{
Sven Laumer \\ University of Bamberg \\ sven.laumer \\ @uni-bamberg.de
}

\author{
Fabian Gubler \\ University of Bamberg \\ fabian.t.gubler \\ @gmail.com
}

\author{
Christian Maier \\ University of Bamberg \\ christian.maier \\ @uni-bamberg.de
}

\author{
Tim Weitzel \\ University of Bamberg \\ tim.weitzel \\ @uni-bamberg.de
}

\begin{abstract}
Based on UTAUT2 and the importance of trust to explain user behavior in relation to recommender systems, we focus on job recommender systems by developing and validating a job recommender system acceptance model. The results of our empirical, survey-based study with 440 job seekers indicate that beside performance expectancy and habit, trust is among the three most important determinants and it is especially relevant for women, passive job seekers and those without experience in using job recommender systems. The paper extends general trust and recommender system research by revealing three moderators for the trust and intention relationship. It contextualizes the UTAUT2 by incorporating trust as an antecedent of a consumer's intention to use and by revealing three moderating effects for this relationship. Hence, it is the basis for further studies investigating the acceptance of job recommender system, which has rather been neglected by prior research.
\end{abstract}

\section{Introduction}

"Recruiting is hard. It's just finding the needle in the haystack" said Steve Jobs while summarizing one of the major challenges of organizations in the $21^{\text {st }}$ century. However, not only organizations have to find the needle in the haystack, also job seekers themselves are looking for their calling which fits best their personal values, attitudes, skills, and capabilities [1]. Job seekers screen plenty of job opportunities and select their perceived most appropriate ones to apply for the job. Given the amount of job opportunities published by organizations, job seekers need to put a lot of effort in identifying the most appropriate ones. Therefore, supporting job seekers has been the focus of several online recruiting services.

In the technology-supported job seeking process, job recommender systems have been deployed to support job seekers in their search for their calling. Recommender systems have been used successfully in e-commerce to support users to find different types of products that fit with their preferences [2]. Their relevance and applicability in the job seeking process has increased with more and more people publishing personal and professional information on social networking platforms. Using this public information and matching it with job opportunities published by organizations, job recommender systems are able to provide appropriate job opportunities to job seekers. Hence, job recommender systems automatically identify the needle in the haystack of job opportunities [3].

Nonetheless, job seekers do not fully accept this automation of the job seeking process [4-6] as only about $50 \%$ are willing to use job recommender system actively in the job seeking process and about 15\% do not even know what job recommender systems are [7]. Therefore, it is relevant to understand which factors determine job seekers' intention to use job recommender systems. These concerns are in line with the general conclusion by Lee and See [8] who point out that "designing trustable technology may be a critical factor in the success of the next generation of automation and computer technology" (p. 76). Given the relevance of job recommender systems in the recruiting context to identify the needle in the haystack of published job opportunities, the challenge of job seekers' acceptance of automation in the recruiting context and the highlighted importance of trust for automated technologies [9], in this paper we intend to answer the following research question:

\section{What is the influence of trust compared to other influencing factors on the intention to use job recommender systems?}

An answer to this question should enable online recruiting services to develop their job recommendation systems such that they focus on the important factors for job seekers to use these systems and trust the recommendations provided. From a theoretical perspective, we need to develop a research model that enables us to analyze the factors determining the intention to use and to reveal influence 
of trust compared to other factors. Therefore, we will develop a job recommender system acceptance model in this paper to explain job seekers' intention to use job recommender systems, which extends the UTAUT2model by the influence of trust on the intention to use [10]. We will also report the results of an empirical study with 440 job seekers to validate the proposed model and discuss its implications.

\section{Related work}

In this section, we will summarize related work on job recommender systems and technology acceptance research to highlight the specific research gap that our approach is intended to fill.

\subsection{Job recommender systems}

Resnick and Varian (1997) [11] first defined the term 'recommender system' by highlighting that the "system value lies in its ability to make good matches between the recommenders and those seeking recommendations" (p. 56). Hence, a recommender system determines the interest of a user in a specific item (e.g. book, song, or movie) by using a variety of information that is related either to the user or to the item. In general, recommender systems address the efforts required to search for specific items that match with user preferences. In the recruiting context, two different types of recommender systems are discussed. First, job recommender systems that match a user profile and the various available job opportunities and then prioritize job opportunities for the job seeker. Second, CV recommender systems that match one job opportunity with user profiles to identify the most appropriate candidates for a specific vacancy $[12,13]$. Hence, the recommendation in the recruiting context is bilateral as recommendations can be made for both the job seeker and the organization. For both types of recommender systems several content-, collaborative-, knowledge-based, and hybrid recommendation algorithms have been investigated [14]. The majority of the literature investigates matching algorithms that address the bilaterally of the recommendation [12, 13, 15], the challenge of the various user characteristics that can be used to match job seekers with jobs [1517], and the consideration of social networks for the matching process $[13,15,18]$. Hence, none of these approaches deals with the acceptance of job recommender systems by job seekers. Nevertheless, job seekers' acceptance is a challenge, as they do not fully accept automation of their job seeking process [4]. Therefore, we intend to fill this gap in the job recommender system literature by analyzing the factors that influence job seekers' intention to use job recommender systems.

\subsection{Technology acceptance}

To understand the acceptance of job recommender systems, we base on the stream of technology acceptance research that assumes that a user's intention predicts the use of a technology [19]. The intention is influenced by several factors, which are focused by various models explaining the use of different kinds of technologies $[19,20]$. These models include the unified theory of acceptance and use of technology (UTAUT) $[10,19]$. The latest extension of the UTAUT theorizes the acceptance and use of technologies by consumers (UTAUT2). It bases on the original UTAUT such that it explains consumers' voluntary use of a technology by a consumer's intention to use this technology. As factors influencing the intention to use IT, UTAUT2 theorizes performance expectations, effort expectations, social influences, facilitating conditions, hedonic motivations, price values, and habits [10]. It also highlights the moderating influence of age, gender, and experiences on these relationships [10] as illustrated by Figure 1 . As we are interested in analyzing the acceptance of a consumer technology, we rely on UTAUT2 in developing the job recommender system acceptance model to explain the intention to use job recommender systems

\subsection{Acceptance of recommender systems and the role of trust}

Given the popularity of recommender systems in the e-commerce context [21] various approaches have theorized and analyzed the acceptance of recommender systems in general [22]. The major implication from these research endeavors is that trust is a key variable to explain the acceptance of recommender systems and related behavior [2, 23, 24]. Hence, these approaches conclude that if an individual trusts a recommender system provider like an e-commerce website related behavior such as online shopping or use can be observed [25, 26].

Trust in a recommendation context is defined as an individual's beliefs in a recommender system's competence, benevolence, and integrity [2]. Competence refers to individual beliefs that the recommendation system performs effectively in specific domains [27]. Hence, it reflects a job seeker's belief that the job recommender system has the ability, skills, and expertise to identify appropriate job opportunities. Benevolence focuses on individual beliefs that the provider of a recommender system or the system itself cares about the individual and one's interest [27]. It models a job seeker's belief that the job recommender system or the provider of the system cares about an individual's job seeking interests. Integrity is an individual's belief that the recommender system and its provider have a set of principles that 
match with the ones of the individual [27]. It focuses on a job seeker's belief that the job recommender system or its provider has a similar set of belief as the job seeker. This definition of trust applies to different temporal contexts [2]. Thus, it reflects that trust develops gradually as individuals continue to interact with a technology [28]. Trust is especially important in the adoption and early use phase when user have less experience with using the technology [29]. Although, prior research has provided several theoretical insights on trust in online environments, prior research also highlights some gaps in the literature. For example, research investigating the role of gender, user experience, or context is required to explain the influence of trust on outcome variables such as the intention to use [28].

In the following, we will adapt this definition of trust to analyze job seekers intention to use a job recommender system. By doing so, we will focus on the gaps identified in the literature about trust in online environments [28].

\section{Research model}

Our job recommender system acceptance model bases on UTAUT2 [10] as it is among the various technology acceptance model the model that focuses explicitly on a consumer context. As discussed, we will extend UTAUT2 by using trust to explain the use of job recommender systems by job seekers as trust is an important variable when investigating the acceptance and use of recommender systems [28].

\subsection{Job seekers' acceptance of job recommender systems based on UTAUT2}

The use of technology by consumers is predicted by consumers' efforts and performance expectations of the technology [10]. Effort expectancy refers to "the degree to which using a technology will provide benefits to consumers in performing certain activities" ([10], p. 159) and performance expectancy to "the degree of ease associated with consumers' use of technology" ([10], p. 159). In the job seeking context it has been shown that performance and effort expectancy predict job seekers' intentions to use online social networks [30]. In line with these results general recommender system acceptance research shows that performance and effort expectancy have an influence on the intention to use recommender systems [31-33]. Job recommender systems are primarily used to facilitate the process of job searches and as this process is associated with high opportunity risks, it is assumed that job seekers only intend to use technologies, which they expect to be useful and easy to use. Hence, we assume based on UTAUT2:
H1: Performance expectancy is positively associated with the intention to use job recommender systems.

H2: Effort expectancy is positively associated with the intention to use job recommender systems.

Moreover, the intention to use a technology could also be influenced by information provided by other individuals [10]. For example, an individual might have used a job recommender system and found a new job using a recommender system. This individual might tell the story to one's friends and recommend using the job recommender as well. Hence, the intention to use the job recommender is next to effort and performance expectations also influenced by the social environment. This fact is modeled by the variable social influence [10], which is "the extent to which consumers perceive that important others believe they should use a particular technology" ([10], p. 159), such that we assume based on UTAUT2:

H3: Social influence is positively associated with the intention to use job recommender systems.

In addition, users need to be provided with the required resources, skills and capabilities [10]. This fact is modeled by the construct facilitating conditions within the UTAUT2 model as it refers to "consumers' perceptions of the resources and support available to perform a behavior" ([10], p. 159). Hence, job seekers with the required resources to access a job recommender system and the skills and capabilities to use it have higher intentions to use the job recommender system, so that we assume based on UTAUT2:

H4: Facilitating conditions (e.g. resources, skills, capabilities) are positively associated with the intention to use job recommender systems.

Beside the well-studied cognitive factors, also hedonic motivations are important when investigating consumer technology acceptance. Hedonic motivations refer to "the fun or pleasure derived from using a technology" ([10], p. 161). When the use of the technology provides pleasure or fun to the user, a user is more intended to use a technology [10, 34]. When job seekers expect the use of job recommender systems to be enjoyable they intend to use it. Hence, we assume based on UTAUT2:

H5: Hedonic motivations are positively associated with the intention to use job recommender systems.

Although job search is usually not a habitual task [35] research in the context of recommender systems and business social networks such as LinkedIn reflects that habit has an influence on the intention to use these system [36]. Habit refers to the "extent to which people tend to perform behaviors automatically because of learning” ([10], p. 159). Job recommender systems are features of these systems. Hence, individuals can 
develop a use habit for online recruiting services in general, which might also influence the use of the specific job recommender feature of these services. Therefore, we theorize that individuals who have a habit to use online recruiting services have a higher intention to use job recommender systems. Hence, following UTAUT2 we assume that:

H6: Habit is positively associated with the intention to use job recommender systems.

Job recommender systems are typically free of charge such that a price-performance ratio, as described by the price value construct of the UTAUT2 [10] cannot be measured in this work. It is defined as "consumers' cognitive tradeoff between the perceived benefits of the applications and the monetary cost for using them" ([10], p. 159). When the technology investigated is free available this construct was also excluded from the analysis in previous studies [37]. Nonetheless, if the job recommender is not free of charge this construct needs to be considered in a job recommender acceptance study. Hence, we assume:

H7: Price value is positively associated with the intention to use job recommender systems.

\subsection{Trust and job seekers' acceptance}

As explained in our motivation we will extend UTAUT2 in this study by the factor 'trust' as a predictor of the intention to use job recommender systems. In studies investigating the use of recommender systems in general the influence of trust has been demonstrated [38]. Moreover, in the job seeking context it is shown that trust towards using business social networks such as LinkedIn is positively associated with the use of these platforms for job searches [30]. Job seekers consider the competence, benevolence, and integrity of the job recommender system in order to evaluate whether they can trust the system and its recommendations [2, 27]. When these aspects are evaluated positively job seekers trust the technology and have a higher intention to use it [2]. This is especially important as the better the recommender system can make recommendations the more users have to publish information that can be used for recommendations. Hence, job seekers need to trust the job recommender system to provide access to personal data (e.g. user profiles in social media) that can be used by the system to make recommendations. In this context it has been shown that users are afraid that their personal data can be misused by a recommendation system [4]. Hence, job seekers will only use those job recommender systems in which they have a high level of trust in terms of evaluating positively the competence, benevolence, and integrity [2] of the job recommender system. Therefore, we assume that
H8: Trust is positively associated with the intention to use job recommender systems.

Trust develops as individuals interact with information technology [28]. In early use phases when users have no experience, trust is more important than in later phases when users learn about the use of the technology [29]. Hence, when job seekers have no experiences in using job recommender systems trust is more important such that we assume that:

H9: Experience moderates the influence of trust on the intention to use job recommender systems such that the influence is stronger for job seekers without experiences in using recommender systems.

Prior research assumes that trust has different effects across genders [28]. For example, Awad and Ragowsky (2008) show that men and women are affected by trust differently as the influence of trust on the intention to shop online is stronger [39]. The rational for this is that the way online social presence is created is different for men and women [40]. Hence, we assume for the acceptance of job recommender systems that:

H10: Gender moderates the influence of trust on the intention to use job recommender systems such that the influence is stronger for women.

Moreover, prior research also expects that the context the technology is used has an influence on the importance of trust [28]. For example, Charki and Josserand (2008) [41] show that the institutional environment of online reverse actions shapes the dynamic of trust. The rationale is that the broader institutional, societal, and market context constitutes the role of trust for behavioral outcomes [28]. In the job search context, two different types of job seekers are considered: Those, who actively search for a new job opportunity (active job seekers) and those, who do not actively search for, but would be willing to change their job (passive job seekers). The first context involves an active engagement and search for job, whereas the second context involves less active engagement. Hence, in the second context passive job seekers need to be provided with job opportunities to stimulate their interest and willingness to consider a new job opportunity. Those job seekers need more trust in the system providing these opportunities automatically to them as those job seekers who actively search for jobs. Hence, we assume for the acceptance of job recommender systems that:

H11: Context moderates the influence of trust on the intention to use job recommender systems such that the influence is stronger for in passive job seeking context.

These hypotheses constitute our job recommender system acceptance model, which is illustrated by Figure 1. 


\section{Research method}

For validating the research model, a quantitative, survey-based study has been conducted, which we will introduce in the following.

\subsection{Study design}

The study is designed to evaluate the acceptance of jobspotting.com. This platform is free of charge. Job seekers can use it by providing access to different data sources (e.g. profiles on LinkedIn) and receive recommendations for job opportunities. Therefore, we designed an online study and invited job seekers and people interested in career-related issues to participate in the study. We established a panel of this population for studies in the recruiting text, which we have used for several studies already. We raffled several prices to motivate job seekers to participate in the study. In total 487 individuals participated in our study. We used several quality criteria provided by our survey tool SoSci Survey to evaluate the quality of the responses. We followed the suggestion by SoSci survey to exclude some participants from our analysis, which contain too many missing values. Hence, we used the responses provided by 440 participants to validate our model. The demographic characteristics are illustrated by Table 1 . The majority are students who look for their first job such that an analysis of the influence of age as suggested by UTAUT 2 [10] is not sufficient with this data set.

Table 1. Demographics $(\mathrm{N}=440)$

\begin{tabular}{|l|l|l|}
\hline Characteristic & Attribute & \\
\hline \multirow{2}{*}{ Gender } & Male & $35.7 \%$ \\
\cline { 2 - 3 } & Female & $64.3 \%$ \\
\hline \multirow{4}{*}{$\begin{array}{l}\text { Age } \\
\text { (mean=24.2years) }\end{array}$} & $<20$ & $6.6 \%$ \\
\cline { 2 - 3 } & $20-24$ & $52.3 \%$ \\
\cline { 2 - 3 } & $25-29$ & $33.6 \%$ \\
\cline { 2 - 3 } & $30-34$ & $4.3 \%$ \\
\cline { 2 - 3 } Job seeking status & $>34$ & $3.2 \%$ \\
\hline \multirow{3}{*}{$\begin{array}{l}\text { Job recommender } \\
\text { system experiences }\end{array}$} & Active & $15.5 \%$ \\
\cline { 2 - 3 } & Passive & $36.1 \%$ \\
\cline { 2 - 3 } & Indifferent & $48.4 \%$ \\
\cline { 2 - 3 } & Yes & $51.1 \%$ \\
\hline \multirow{2}{*}{ No } & $48.9 \%$ \\
\hline
\end{tabular}

\subsection{Measurement items}

Within the survey, we introduced the system by showing a short video clip to the survey participants and we ensured that everybody has read the introduction and watched the video as we disabled the "continue" button for a while. Afterwards, we ask whether participants intend to use this job recommender systems and how they evaluate it using our job recommender acceptance model. We excluded the price value variable, as the system is free of charge. The remaining variables were measured using the items provided by [10]. Trust was captured using a scale provided by [42] (see Table 2).

Table 2. Measurement items

(7-point Likert scale from strongly agree to strongly disagree)

\begin{tabular}{|c|c|c|}
\hline Construct & Item & Loading \\
\hline \multirow{3}{*}{$\begin{array}{l}\text { Performance } \\
\text { expectancy } \\
(\mathrm{PE})\end{array}$} & I find jobspotting.com useful for me. & 0.901 \\
\hline & $\begin{array}{l}\text { Using jobspotting.com helps me to find } \\
\text { a new job more quickly. }\end{array}$ & 0.890 \\
\hline & $\begin{array}{l}\text { Using jobspotting.com would improve } \\
\text { my job search productivity. }\end{array}$ & 0.848 \\
\hline \multirow{4}{*}{$\begin{array}{l}\text { Effort } \\
\text { expectancy } \\
(\mathrm{EE})\end{array}$} & $\begin{array}{l}\text { Learning how to use jobspotting.com is } \\
\text { easy for me. }\end{array}$ & 0.867 \\
\hline & $\begin{array}{l}\text { My interaction with jobspotting.com is } \\
\text { clear and understandable. }\end{array}$ & 0.882 \\
\hline & $\begin{array}{l}\text { I find mobile jobspotting.com easy to } \\
\text { use. }\end{array}$ & 0.903 \\
\hline & $\begin{array}{l}\text { It is easy for me to become skillful at } \\
\text { using jobspotting.com. }\end{array}$ & 0.909 \\
\hline \multirow{3}{*}{$\begin{array}{l}\text { Social } \\
\text { influence } \\
\text { (SI) }\end{array}$} & $\begin{array}{l}\text { People who are important to me think } \\
\text { that I should use jobspotting.com. }\end{array}$ & 0.948 \\
\hline & $\begin{array}{l}\text { People who influence my behavior } \\
\text { think that I should use jobspotting.com. }\end{array}$ & 0.968 \\
\hline & $\begin{array}{l}\text { People whose opinions that I value } \\
\text { prefer that I use jobspotting.com. }\end{array}$ & 0.949 \\
\hline \multirow{3}{*}{$\begin{array}{l}\text { Facilitating } \\
\text { conditions } \\
\text { (FC) }\end{array}$} & $\begin{array}{l}\text { I have the resources necessary to use } \\
\text { jobspotting.com. }\end{array}$ & 0.804 \\
\hline & $\begin{array}{l}\text { I have the knowledge necessary to use } \\
\text { jobspotting.com. }\end{array}$ & 0.837 \\
\hline & $\begin{array}{l}\text { Jobspotting.com.is compatible with } \\
\text { other technologies I use. }\end{array}$ & 0.863 \\
\hline \multirow{3}{*}{$\begin{array}{l}\text { Hedonic } \\
\text { motivation } \\
(\mathrm{HM})\end{array}$} & Using jobspotting.com is fun. & 0.903 \\
\hline & Using jobspotting.com is enjoyable. & 0.919 \\
\hline & $\begin{array}{l}\text { Using jobspotting.com is very } \\
\text { entertaining. }\end{array}$ & 0.763 \\
\hline \multirow[t]{3}{*}{ Habit (HA) } & $\begin{array}{l}\text { The use of online recruiting services has } \\
\text { become a habit for me. }\end{array}$ & 0.848 \\
\hline & $\begin{array}{l}\text { I must use online recruiting services } \\
\text { when I look for a job. }\end{array}$ & 0.726 \\
\hline & $\begin{array}{l}\text { Using online recruiting services has } \\
\text { become natural to me }\end{array}$ & 0.911 \\
\hline \multirow[t]{5}{*}{ Trust (TR) } & Jobspotting.com is deceptive. & 0.849 \\
\hline & $\begin{array}{l}\text { I am suspicious of jobspotting.com's } \\
\text { intent, action, or outputs. }\end{array}$ & 0.701 \\
\hline & Jobspotting.com has integrity. & 0.770 \\
\hline & Jobspotting.com is dependable. & 0.818 \\
\hline & I can trust jobspotting.com. & 0.786 \\
\hline \multirow{3}{*}{$\begin{array}{l}\text { Behavioral } \\
\text { intention } \\
\text { (BI) }\end{array}$} & $\begin{array}{l}\text { I intend to continue using } \\
\text { jobspotting.com in the future. }\end{array}$ & 0.944 \\
\hline & $\begin{array}{l}\text { I will always try to jobspotting.com } \\
\text { when searching for a job. }\end{array}$ & 0.930 \\
\hline & $\begin{array}{l}\text { I plan to continue to use } \\
\text { jobspotting.com frequently. }\end{array}$ & 0.928 \\
\hline Age & How old are you? & $\begin{array}{c}\text { Single } \\
\text { item }\end{array}$ \\
\hline Gender & $\begin{array}{l}\text { Please indicate your gender: } \\
\text { (male | female) }\end{array}$ & $\begin{array}{c}\text { Single } \\
\text { item }\end{array}$ \\
\hline Experience & $\begin{array}{l}\text { Do you have experiences in using a job } \\
\text { recommender system: } \\
\text { (yes } \mid \text { no) }\end{array}$ & $\begin{array}{l}\text { Single } \\
\text { item }\end{array}$ \\
\hline $\begin{array}{l}\text { Job seeking } \\
\text { role }\end{array}$ & $\begin{array}{l}\text { How would you describe yourself: } \\
\text { (active job seeker | passive job seeker | } \\
\text { indifferent) }\end{array}$ & $\begin{array}{l}\text { Single } \\
\text { item }\end{array}$ \\
\hline
\end{tabular}




\section{Research results}

We transferred the proposed job recommender system acceptance model into a structural equation model [43] and used the partial least squares (PLS) method calculated using SmartPLS 3.2.1 software [44].

\subsection{Measurement model}

Our model contains first-order reflective constructs, so that content validity, indicator validity, construct reliability and discriminant validity have to be assessed to validate the measurement model [45]. Using selfreported data might induce a common method bias (CMB) into survey-based research [46]. In order to test whether our results are affected by CMB, we used Harman's single factor test, examined the correlation matrix and used an CMB factor in the PLS modelUsing these test we do not observe signs of $\mathrm{CMB}$ influence.

5.1.1. Content validity. As discussed above, the items used have proven to be robust in prior research approaches and are thus suitable measurement items.
We simply adapted the items to fit our context where necessary, based on a discussion with job seekers.

5.1.2. Indicator reliability. It indicates the ratio of the variance of an indicator that comes from the latent variables. Therefore, each value has to be above 0.707 [47]. This reliability condition is fulfilled for all indicators. Moreover, each loading has a significance level of at least 0.001 (see Table 2). We tested this using a bootstrap method with 500 samples.

5.1.3. Construct reliability. Quality at the construct level is indicated by composite reliability (CR) and average variance extracted (AVE) [48], whereby CR has to be at least 0.7 and AVE has to be higher than 0.5 (see Table 3). We meet both criteria in our study.

5.1.4. Discriminant validity. For assessing this criterion [49], the square root of AVE should be greater than the corresponding construct correlations $[48,50]$. The values included on the diagonal of latent variable correlation (see Table 3) confirm that the measurement model is valid. Moreover, the heterotraitmonotrait (HTMT) ratio of correlations criterion is used to assess discriminant validity [51].

Table 3. Measurement model validation

(Square root of AVE on the diagonal)

\begin{tabular}{|c|c|c|c|c|c|c|c|c|c|c|}
\hline & CR & AVE & BI & PE & EE & SI & FC & HM & HA & TR \\
\hline Behavioral intention (BI) & 0.954 & 0.873 & 0.934 & & & & & & & \\
\hline Performance expectancy (PE) & 0.911 & 0.774 & 0.690 & 0.880 & & & & & & \\
\hline Effort expectancy (EE) & 0.939 & 0.793 & 0.407 & 0.472 & 0.890 & & & & & \\
\hline Social influence (SI) & 0.969 & 0.912 & 0.358 & 0.373 & 0.143 & 0.955 & & & & \\
\hline Facilitating conditions (FC) & 0.873 & 0.697 & 0.378 & 0.397 & 0.708 & 0.175 & 0.835 & & & \\
\hline Hedonic motivation (HM) & 0.898 & 0.748 & 0.466 & 0.419 & 0.341 & 0.271 & 0.308 & 0.865 & & \\
\hline Habit (HA) & 0.870 & 0.693 & 0.683 & 0.595 & 0.288 & 0.386 & 0.302 & 0.385 & 0.832 & \\
\hline Trust (TR) & 0.890 & 0.618 & 0.581 & 0.545 & 0.347 & 0.331 & 0.290 & 0.403 & 0.502 & 0.786 \\
\hline
\end{tabular}

Table 4. Between groups analysis (moderation analysis)

$\left({ }^{* * *} \mathbf{p}<0.001,{ }^{* *} \mathbf{p}<0.01,{ }^{*} \mathbf{p}<0.05,{ }^{\text {ns }} \mathbf{p}>0.05\right.$

\begin{tabular}{|c|c|c|c|c|c|c|}
\hline \multirow[t]{2}{*}{$\begin{array}{l}\text { Independent } \\
\text { variable }\end{array}$} & \multicolumn{6}{|c|}{$\begin{array}{l}\text { Dependent variable: Behavioral intention } \\
\left(\mathbf{f}^{2}\right)\end{array}$} \\
\hline & No experience & Experience & Men & Women & Active job seeker & Passive job seeker \\
\hline $\begin{array}{l}\text { Performance } \\
\text { expectancy }\end{array}$ & $\begin{array}{c}0.387^{* * *} \\
(0.237) \\
\end{array}$ & $\begin{array}{c}0.246^{* * *} \\
(0.07)\end{array}$ & $\begin{array}{l}0.208^{* * *} \\
(0.062)\end{array}$ & $\begin{array}{c}0.361^{* * *} \\
\left(0.171^{\prime}\right.\end{array}$ & $\begin{array}{l}0.214^{* *} \\
(0.052)\end{array}$ & $\begin{array}{l}0.221^{* *} \\
(0.05)\end{array}$ \\
\hline $\begin{array}{l}\text { Effort } \\
\text { expectancy }\end{array}$ & $\begin{array}{l}0.021^{\text {ns }} \\
(0.001)\end{array}$ & $\begin{array}{l}0.033^{\text {ns }} \\
(0.001)\end{array}$ & $\begin{array}{l}0.189^{* * * *} \\
(0.049)\end{array}$ & $\begin{array}{l}-0.058^{\mathrm{ns}} \\
(0.004)\end{array}$ & $\begin{array}{l}0.076^{\text {ns }} \\
(0.006)\end{array}$ & $\begin{array}{l}-0.03^{\text {ns }} \\
(0.001)\end{array}$ \\
\hline $\begin{array}{l}\text { Social } \\
\text { influence }\end{array}$ & $\begin{array}{l}0.082^{\text {ns }} \\
(0.019)\end{array}$ & $\begin{array}{l}-0.064^{\text {ns }} \\
(0.007)\end{array}$ & $\begin{array}{l}0.053^{\text {ns }} \\
(0.007)\end{array}$ & $\begin{array}{l}-0.004^{\text {ns }} \\
(0.001)\end{array}$ & $\begin{array}{l}0.117^{\text {ns }} \\
(0.033)\end{array}$ & $\begin{array}{l}0.037^{\text {ns }} \\
(0.003)\end{array}$ \\
\hline $\begin{array}{l}\text { Facilitating } \\
\text { conditions }\end{array}$ & $\begin{array}{l}0.012^{\text {ns }} \\
(0.00)\end{array}$ & $\begin{array}{l}0.022^{\text {ns }} \\
(0.001)\end{array}$ & $\begin{array}{l}-0.042^{\text {ns }} \\
(0.003)\end{array}$ & $\begin{array}{l}0.092^{\text {ns }} \\
(0.01)\end{array}$ & $\begin{array}{l}0.061^{\text {ns }} \\
(0.004)\end{array}$ & $\begin{array}{l}0.125^{\text {ns }} \\
(0.016)\end{array}$ \\
\hline $\begin{array}{l}\text { Hedonic } \\
\text { motivation }\end{array}$ & $\begin{array}{l}0.008^{\text {ns }} \\
(0.00)\end{array}$ & $\begin{array}{l}0.201^{* * *} \\
(0.069)\end{array}$ & $\begin{array}{l}0.113^{* * *} \\
(0.029)\end{array}$ & $\begin{array}{l}0.110^{* * * *} \\
(0.024)\end{array}$ & $\begin{array}{l}-0.03^{\text {ns }} \\
(0.002)\end{array}$ & $\begin{array}{l}0.008^{\text {ns }} \\
(0.00)\end{array}$ \\
\hline Habit & $\begin{array}{l}0.325^{* * * *} \\
(0.202)\end{array}$ & $\begin{array}{l}0.339^{* * * *} \\
(0.153)\end{array}$ & $\begin{array}{l}0.433^{* * * *} \\
(0.327)\end{array}$ & $\begin{array}{l}0.300^{* * * *} \\
(0.134)\end{array}$ & $\begin{array}{l}0.483^{* *} \\
(0.321)\end{array}$ & $\begin{array}{c}0.364^{* * * *} \\
(0.191)\end{array}$ \\
\hline \multirow[t]{2}{*}{ Trust } & $\begin{array}{l}0.214^{* * *} \\
(0.096)\end{array}$ & $\begin{array}{c}0^{171}{ }^{* * *} \\
(0.04)\end{array}$ & $\begin{array}{l}\text { 0.111 }^{*} \\
(0.024)\end{array}$ & $\begin{array}{l}\mathbf{0 . 1 8 8}^{* * *} \\
(0.056)\end{array}$ & $\begin{array}{l}0.109^{\text {ns }} \\
(0.023)\end{array}$ & $\begin{array}{l}0.25^{* * *} \\
(0.081)\end{array}$ \\
\hline & \multicolumn{2}{|c|}{ H9: supported } & \multicolumn{2}{|c|}{ H10: supported } & \multicolumn{2}{|c|}{ H11: supported } \\
\hline
\end{tabular}


Using the absolute HTMT0.85 criterion indicates that discriminant validity is not an issue in our research (highest value is 0.708 for effort expectancy and facilitating conditions).

\subsection{Structural model}

In order to evaluate the structural model, we use the coefficient of determination $\left(\mathrm{R}^{2}\right)$ and level of significance of each path coefficient [43]. Table 5 indicates that $63.2 \%$ of the intention to use job recommender systems can be explained by the seven independent variables tested. Regarding the hypotheses modeled by the research model, we can conclude that we are able to detect a significant influence of performance expectancy, hedonic motivation, habit, and trust on the intention to use job recommender systems. However, we have to reject the hypotheses regarding the influence of effort expectancy, social influence, and facilitating conditions (see Table 5). Regarding effect size $\left(\mathrm{f}^{2}\right)$ we can observe that habit, performance expectancy, and trust are the three most important determinants for the intention to use.

Table 5. Structural model validation $(* * * \mathrm{p}<0.001$, ns $\mathrm{p}>0.1)$

\begin{tabular}{|c|c|c|c|c|c|}
\hline $\mathbf{H} \#$ & IV & DV: BI & Comment & $\mathbf{f}^{2}$ & $\begin{array}{c}\mathbf{R}^{2} \\
\text { (BI) }\end{array}$ \\
\hline H1 & PE & $0.312^{* * * *}$ & Supported & 0.127 & \multirow{7}{*}{0.632} \\
\hline H2 & $\mathbf{E E}$ & $0.036^{\mathrm{ns}}$ & Not supported & 0.002 & \\
\hline H3 & SI & $0.013^{\text {ns }}$ & Not supported & 0.000 & \\
\hline H4 & FC & $0.041^{\mathrm{ns}}$ & Not supported & 0.002 & \\
\hline H5 & HM & $0.108^{* * *}$ & Supported & 0.023 & \\
\hline H6 & HA & $0.345^{* * *}$ & Supported & 0.183 & \\
\hline H7 & TR & $0.166^{* * *}$ & Supported & 0.047 & \\
\hline
\end{tabular}

The three moderation hypotheses were evaluated using between group analysis [52, 53]. Therefore, we split the dataset into separate files containing either men or women, active or passive job seeker, or participants with or without experience in using job recommender systems. The results are illustrated by Table 4. Regarding our hypotheses the different effects of trust (TR) need to be analyzed. Our results confirm the three moderation hypotheses as the effect of trust on the intention to use job recommender systems is stronger for women, passive job seekers and those job seekers with no experience in using job recommender systems and these effects are significantly different (ttest, $\mathrm{p}<0.01$ ). Hence, our hypotheses can be supported.

\section{Discussion and implications}

Our research was motivated to analyze the influence of trust compared to other variables predicting the intention to use job recommender systems. We observe that performance expectance, hedonic motivations, habit, and trust are important predictors of the intention to use job recommender systems. Hence, job seekers who evaluate the performance of job recommender systems positively, who enjoy using it, who trust it, and who have a habit to use online recruiting services in general have a high intention to use job recommender systems. Moreover, for the influence of trust we can conclude from our analysis that trust is among the three most important determinants of the intention to use job recommender systems The influence of trust is especially important for women, passive job seekers and job seekers without job recommender system use experience. We will discuss the implications of these results to the literature in the following.

First, given the review provided in section 2 on job recommender systems we provide an empirical study that evaluates the acceptance of job recommender systems by job seekers. The majority of prior work as summarized by section 2 focuses on the design of algorithms [3, 54]. We contribute to this stream of research by starting a new discussion about job seekers' intention to use job recommender systems as only those job recommender systems will be successful which are used by job seekers [55]. Our first study of a job recommender system acceptance highlights that performance expectancy, hedonic motivation, and trust are important beliefs about job recommender systems and that especially those job seekers who have a habit of using online recruiting services are intended to use job recommender systems. Providers of these platforms might consider these results to enable a positive user experience in terms of usefulness and fun and to highlight the trustworthiness of the provider. If job seekers consider these three variables positive, they intend to use the job recommender system. Figure 1 summarizes our proposed and evaluated job recommender system acceptance model, which is the underlying theoretical model for further studies investigating job seekers' acceptance of job recommender systems.

Second, regarding the research dealing with trust and recommender systems in general we followed the call for an investigation of gender, experience, and context [28] and theorized the moderating influence of these three factors on the relationship between trust and the intention to use. Our results confirm these moderation effects such that we contribute to this stream of research by highlighting that trust is especially important for women, for users with less experiences in using the technology, and for users in a specific context (here: passive job search). General 
trust and recommender system research have provided some first indications for these effects [29, 39, 41] and we are able to confirm them in the job recommender system context. Figure 1 illustrates the general effect of trust on intention to use which is known from prior research and highlights our contribution in terms of the moderating variables.

Third, we also contribute the general UTAUT2 model [10]. It focuses especially on consumer acceptance and provides variables that are especially important in a consumer technology context. Nonetheless, as highlighted by general discussions on automation technology trust is an important factor for technologies that automate consumer tasks as searching for a job, which is not considered by UTAUT2. Therefore, we theorize the influence of trust on the intention to use and we are able to confirm these effects by our empirical study. However, we are not the first study who extend UTAUT or UTAUT2 by trust [e.g. 56], but we extend these prior research endeavors by theorizing and providing empirical evidence for the moderating influence of gender, experiences and context. Therefore, we provide an updated UTAUT2 model contextualized for the job recommender system context that is extended by trust and the moderating influences. Figure 1 illustrates the resulting model and highlights especially the new effects provided by our research.

Nonetheless, our approach and contributions are limited by some facts. First, we only consider behavioral intention as independent variable. To further extend the model, a focus on actual use is required as well. Second, we only conducted one study focusing on one job recommender system and conducted a one point in time study in one particular culture setting. The results might be different for different job recommender systems and in different cultural contexts. Furthermore, as our study participants are rather younger, an analysis of age was not sufficient. Third, we focused on those moderators that were related to the UTAUT model or especially highlighted by general recommender system research. Additional factors such as user personality might also moderate the relationships tested which we have not controlled for.

Given these limitations and considering the discussed implications future research can use our approach to further extend our understanding of trust and the acceptance of job recommender systems. First, future research should replicate our study for different job recommender systems to confirm that the identified effect for jobspotting.com are consistent when focusing on different systems and user groups. Second, as the importance of trust has been highlighted future research studies can focus on the antecedents of trust and the trust building process to investigate under which conditions job seekers trust a job recommender system. This type of research might identify specific design characteristics that foster job seekers to trust job recommender systems. Third, given the focus on the early adoption phases future research can test the applicability of the model in later use phases to reveal whether these different phases also influence the importance of trust for explaining behavioral intention. Given the fact that more experienced users require lower level of trust to intend using a job recommendation system we assume that with an increasing experience in using the particular job recommender system the importance of trust decreases. Hence, our approach is the base for further studies in the job recommender system area that focus on user acceptance of these systems to inform the three identified research streams about designing these systems by accounting for the factors being important for the user of these systems.

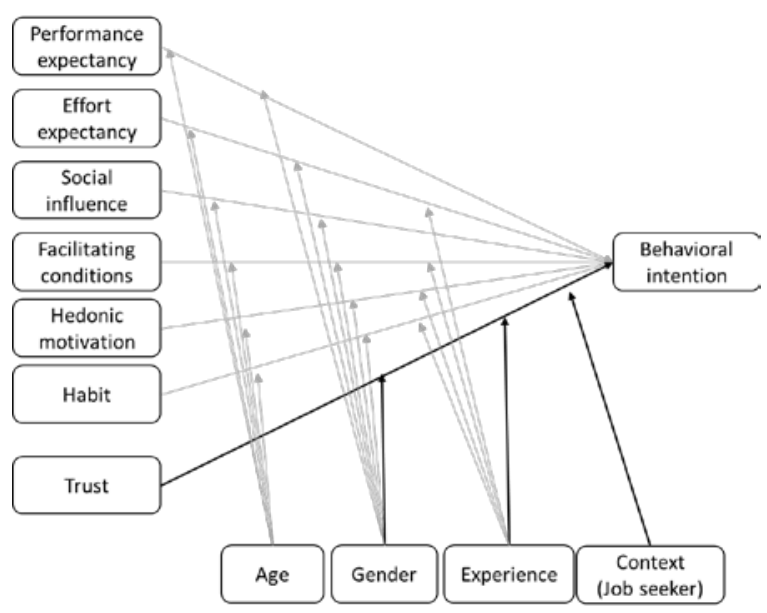

Figure 1. Job recommender system acceptance model (new relationships compared to UTAUT2 are shown as darker lines)

\section{References}

[1] J. M. Berg, A. M. Grant, and V. Johnson, "When Callings Are Calling: Crafting Work and Leisure in Pursuit of Unanswered Occupational Callings," Organization Science, vol. 21, no. 5, pp. 973-994, 2010.

[2] I. Benbasat and W. Wang, "Trust in and adoption of online recommendation agents," Journal of the Association for Information Systems, vol. 6, no. 3, p. 4, 2005.

[3] S. Laumer and A. Eckhardt, "Help to find the needle in a haystack," in Proceedings of the special interest group on management information system's 47th annual conference on Computer personnel research - SIGMISCPR '09, New York, New York, USA: ACM Press, 2009, p. 7. 
[4] K. Shyong, D. Frankowski, and J. Riedl, "Do you trust your recommendations? An exploration of security and privacy issues in recommender systems," in Emerging Trends in Information and Communication Security: Springer, 2006, pp. 14-29.

[5] A. Eckhardt, S. Laumer, C. Maier, and T. Weitzel, "The transformation of people, processes, and IT in erecruiting: Insights from an eight-year case study of a German media corporation,” Employee Relations, vol. 36, no. 4, pp. 415-431, 2014.

[6] S. Lang, S. Laumer, C. Maier, and A. Eckhardt, "Drivers, challenges and consequences of E-recruiting," in Proceedings of the 49th SIGMIS annual conference on Computer personnel research - SIGMIS-CPR '11: ACM Press, 2011, p. 26.

[7] T. Weitzel et al., "Recruiting Trends 2017: Active Sourcing und Social Recruiting," Otto-Friedrich University of Bamberg, Bamberg, 2017. [Online] Available: https://www.unibamberg.de/fileadmin/uni/fakultaeten/wiai_lehrstuehle/i sdl/2_Active_Sourcing_20170210_WEB.pdf.

[8] J. D. Lee and K. A. See, "Trust in Automation: Designing for Appropriate Reliance,” Human Factors: The Journal of the Human Factors and Ergonomics Society, vol. 46, no. 1, pp. 50-80, 2004.

[9] T. Wirtky, S. Laumer, A. Eckhardt, and T. Weitzel, “On the Untapped Value of IT in HRM - a Literature Review," Communications of the Association for Information Systems (CAIS), vol. 38, no. 2, http://aisel.aisnet.org/cais/vol38/iss1/2, 2015.

[10] V. Venkatesh, J. Y. L. Thong, and X. Xu, “Consumer acceptance and use of information technology: extending the unified theory of acceptance and use of technology,” MIS Quarterly, vol. 36, no. 1, pp. 157178, 2012.

[11] P. Resnick and H. R. Varian, "Recommender systems," Communications of the ACM, vol. 40, no. 3, pp. 56-58, 1997.

[12] H. Yu, C. Liu, and F. Zhang, "Reciprocal recommendation algorithm for the field of recruitment," Journal of Information \& Computational Science, vol. 8, no. 16, pp. 4061-4068, 2011.

[13] J. Malinowski, T. Keim, O. Wendt, and T. Weitzel, "Matching People and Jobs: A Bilateral Recommendation Approach,” in Proceedings of the 39th Annual Hawaii International Conference on System Sciences (HICSS’06), 2006, 137c-137c.

[14] S. T. Al-Otaibi and M. Ykhlef, "A survey of job recommender systems," International Journal of the Physical Sciences, vol. 7, no. 29, pp. 5127-5142, 2012.

[15] R. Buettner, "A Framework for Recommender Systems in Online Social Network Recruiting: An Interdisciplinary Call to Arms,” in 2014 47th Hawaii International Conference on System Sciences: IEEE, 2014, pp. 1415-1424.

[16] W. Hong, S. Zheng, H. Wang, and J. Shi, “A Job Recommender System Based on User Clustering,” Journal of Computers, vol. 8, no. 8, 2013.

[17] A. Gupta and D. Garg, “Applying data mining techniques in job recommender system for considering candidate job preferences,” in 2014 International
Conference on Advances in Computing, Communications and Informatics (ICACCI), pp. 14581465.

[18] J. Malinowski, T. Weitzel, and T. Keim, "Decision support for team staffing: An automated relational recommendation approach,” Decision Support Systems, vol. 45, no. 3, pp. 429-447, 2008.

[19] V. Venkatesh, M. G. Morris, G. B. Davis, and F. D. Davis, "User acceptance of information technology: toward a unified view,” MIS Quarterly, vol. 27, no. 3, pp. 425-478, 2003.

[20] F. D. Davis, "Perceived usefulness, perceived ease of use, and user acceptance of information technology," MIS Quarterly, vol. 13, no. 3, pp. 319-340, 1989.

[21] B. Xiao and I. Benbasat, "E-Commerce Product Recommendation Agents: Use, Characteristics, and Impact,” MIS Quarterly, vol. 31, no. 1, pp. 137-209, 2007.

[22] S. X. Komiak and I. Benbasat, "Understanding customer trust in agent-mediated electronic commerce, web-mediated electronic commerce, and traditional commerce,” Information Technology and Management, vol. 5, no. 1-2, pp. 181-207, 2004.

[23] S. Y. X. Komiak and I. Benbasat, "A two-process view of trust and distrust building in recommendation agents: A process-tracing study," Journal of the Association for Information Systems, vol. 9, no. 12, p. 727, 2008.

[24] W. Wang and I. Benbasat, "Recommendation agents for electronic commerce: Effects of explanation facilities on trusting beliefs," Journal of Management Information Systems, vol. 23, no. 4, pp. 217-246, 2007.

[25] K. H. Lim, C. L. Sia, M. K. O. Lee, and I. Benbasat, "Do I trust you online, and if so, will I buy? An empirical study of two trust-building strategies," Journal of Management Information Systems, vol. 23, no. 2, pp. 233-266, 2006.

[26] D. Kim and I. Benbasat, "The effects of trust-assuring arguments on consumer trust in Internet stores: Application of Toulmin's model of argumentation," Information Systems Research, vol. 17, no. 3, pp. 286300, 2006.

[27] D. H. McKnight, V. Choudhury, and C. Kacmar, "Developing and Validating Trust Measures for eCommerce: An Integrative Typology,” Information Systems Research, vol. 13, no. 3, pp. 334-359, 2002.

[28] D. Gefen, I. Benbasat, and P. A. Pavlou, "A Research Agenda for Trust in Online Environments,” Journal of Management Information Systems, vol. 24, no. 4, pp. 275-286, 2008.

[29] D. Gefen, E. Karahanna, and D. W. Straub, "Inexperience and experience with online stores: The importance of tam and trust,” IEEE Transactions on Engineering Management, vol. 50, no. 3, pp. 307-321, 2003.

[30] M. Plummer, S. R. Hiltz, and L. Plotnick, "Predicting intentions to apply for jobs using social networking sites: an exploratory study,” in System Sciences (HICSS), 2011 44th Hawaii International Conference on, 2011, pp. 1-10.

[31] R. Hu and P. Pu, "Acceptance issues of personalitybased recommender systems," in Proceedings of the 
third ACM conference on Recommender systems, 2009, pp. 221-224.

[32] D. Baier and E. Stüber, “Acceptance of recommendations to buy in online retailing," Journal of Retailing and Consumer Services, vol. 17, no. 3, pp. 173-180, 2010.

[33] O. Oechslein, M. Fleischmann, and T. Hess, “An Application of UTAUT2 on Social Recommender Systems: Incorporating Social Information for Performance Expectancy,” in 47th Hawaii International Conference on System Sciences (HICSS), 2014, pp. 3297-3306.

[34] H. van der Heijden, "User acceptance of hedonic information systems,” MIS Quarterly, pp. 695-704, 2004.

[35] E. A. J. van Hooft, C. R. Wanberg, and G. van Hoye, "Moving beyond job search quantity: Towards a conceptualization and self-regulatory framework of job search quality,” Organizational Psychology Review, 2041386612456033, 2012.

[36] R. Buettner, “Getting a Job via Career-oriented Social Networking Sites: The Weakness of Ties,” in 49th Annual Hawaii International Conference on System Sciences. Kauai, Hawaii: IEEE. do i, 2016.

[37] A. Raman and Y. Don, "Preservice teachers' acceptance of learning management software: An Application of the UTAUT2 Model,” International Education Studies, vol. 6, no. 7, p. 157, 2013.

[38] W. Wang and I. Benbasat, "Attributions of Trust in Decision Support Technologies: A Study of Recommendation Agents for E-Commerce,” Journal of Management Information Systems, vol. 24, no. 4, pp. 249-273, 2008.

[39] N. F. Awad and A. Ragowsky, "Establishing Trust in Electronic Commerce Through Online Word of Mouth: An Examination Across Genders,” Journal of Management Information Systems, vol. 24, no. 4, pp. 101-121, 2008.

[40] D. Gefen and D. W. Straub, "Gender differences in the perception and use of e-mail: An extension to the technology acceptance model,” MIS Quarterly, pp. 389-400, 1997.

[41] M. H. Charki and E. Josserand, "Online Reverse Auctions and the Dynamics of Trust," Journal of Management Information Systems, vol. 24, no. 4, pp. 175-197, 2008.

[42] J.-Y. Jian, A. M. Bisantz, and C. G. Drury, "Foundations for an Empirically Determined Scale of Trust in Automated Systems," International Journal of Cognitive Ergonomics, vol. 4, no. 1, pp. 53-71, 2000.

[43] W. W. Chin, "The partial least squares approach to structural equation modeling," Modern methods for business research, vol. 295, no. 2, pp. 295-336, 1998.

[44] C. M. Ringle, S. Wende, and J.-M. Becker, SmartPLS 3: SmartPLS GmbH.
[45] R. P. Bagozzi, “The role of measurement in theory construction and hypothesis testing: toward a holistic model," Conceptual and theoretical developments in marketing, vol. 8, pp. 15-32, 1979.

[46] P. M. Podsakoff, S. B. MacKenzie, J.-Y. Lee, and N. P. Podsakoff, "Common method biases in behavioral research: A critical review of the literature and recommended remedies,” Journal of Applied Psychology, vol. 88, no. 5, pp. 879-903, 2003.

[47] E. G. Carmines and R. A. Zeller, Reliability and validity assessment: Sage Publications, 1979.

[48] C. Fornell and D. F. Larcker, "Evaluating structural equation models with unobservable variables and measurement error,” Journal of Marketing Research, pp. 39-50, 1981.

[49] D. T. Campbell and D. W. Fiske, "Convergent and discriminant validation by the multitrait-multimethod matrix,” Psychological Bulletin, vol. 56, no. 2, pp. 81105, 1959.

[50] J. Hulland, "Use of partial least squares (PLS) in strategic management research: a review of four recent studies,” Strategic Management Journal, vol. 20, no. 2, pp. 195-204, 1999.

[51] J. Henseler, C. M. Ringle, and M. Sarstedt, “A new criterion for assessing discriminant validity in variancebased structural equation modeling," Journal of the Academy of Marketing Science, pp. 1-21, 2015.

[52] I. Qureshi and D. R. Compeau, “Assessing BetweenGroup Differences in Information Systems Research: A Comparision of Covariance-and Component-Based SEM,” Management Information Systems Quarterly, vol. 33, no. 1, p. 12, 2009.

[53] W. W. Chin and J. Dibbern, “An Introduction to a Permutation Based Procedure for Multi-Group PLS Analysis: Results of Tests of Differences on Simulated Data and a Cross Cultural Analysis of the Sourcing of Information System Services Between Germany and the USA,” in Handbook of Partial Least Squares, V. Esposito Vinzi, W. W. Chin, J.?r. Henseler, and H. Wang, Eds., Berlin, Heidelberg: Springer Berlin Heidelberg, 2010, pp. 171-193.

[54] S. Laumer, A. Eckhardt, and T. Weitzel, "Online Gaming to Apply for Jobs - The Impact of Self- and EAssessment on Staff Recruitment,” in 2009 42nd Hawaii International Conference on System Sciences: IEEE, 2009, pp. 1-10.

[55] S. Laumer, A. Eckhardt, and T. Weitzel, "Online Gaming to Find a New Job - Examining Job Seekers' Intention to Use Serious Games as a Self-Assessment Tool,” Zeitschrift für Personalforschung (ZfP) (German Journal of Research in Human Resource Management), vol. 26, no. 3, pp. 218-240, 2012.

[56] L. C. Schaupp and L. Carter, "The impact of trust, risk and optimism bias on E-file adoption,” Information Systems Frontiers, vol. 12, no. 3, pp. 299-309, 2010. 